\title{
$\underline{\text { Time Frames and Legal Indeterminacy }}$
}

Abstract: A consensus has long been established that adherents of the Critical Legal School (and to a lesser extent, Legal Realism) exaggerated their claims of law's indeterminacy. This paper however, attempts to resurrect the indeterminacy debate by articulating, developing and elevating a particular strand of it; namely, the use of unrestrained time frames in factual construction. This claims that factual construction in adjudication is, in part, contingent on the time frames adopted, though absent some metaprinciple on whether to adopt broad or narrow time frames, indeterminacy rears its head. The paper primarily argues that time frame indeterminacy is important as it actually underwrites the attacks levelled by both Critical Legal Studies (CLS) and American Legal Realism (ALR) on legal liberalism. It nourishes ALR critiques by enriching the strict and loose articulations of precedent authored by Karl Llewellyn, and also connects some of the definitive themes that underline the CLS literature, specifically the rules-standards and free will-determinism contradictions in legal liberal discourse. Coupled with an emerging interest in the role of time and temporality in law and regulation, it is hoped this paper will contribute to an emergent corpus of work by re-energising still pertinent debates of indeterminacy.

Key Words: Legal Indeterminacy, Time, Adjudication, Critical Legal Studies, American Legal Realism,

Though the Critical Legal Studies (CLS) movement is often considered the successor, or at least progeny, of American Legal Realism (ALS), the former moved beyond the liberal paradigm that the likes of Oliver Wendell Holmes and Karl Llewellyn were still committed to. Whereas the legal realist still saw legal rules and reasoning as an autonomous normative order, the 'Crits' argued that law did not have an existence outside the ideological battles within society ${ }^{1}$ law is politics ${ }^{2}$ as it were. Their convergence however, lay in their mutual revolt against formalism $^{3}$ and law's paramount claim to determinacy. In short, both intellectual movements sought to problematise the extent to which judges were constrained in their capacity as declarers or appliers of law. This is important as most liberal, democratic polities seek to uphold a version of the separation of powers contingent on

\footnotetext{
${ }^{1}$ Robert Gordon, 'Law and Ideology' (1988) 3,1 Tikkun

${ }^{2}$ David Kairys (ed.) The Politics of Law (Basic Books, 1988)

${ }^{3}$ Morton G White, 'Social Thought in America: The Revolt Against Formalism' (1947) 8, 2 Journal of the History of Ideas
} 
their constitutional milieus. One of the most emphatic pronouncements of this in the UK for example, was Lord Diplock in the case of Duport Steel $v$. Sirs ${ }^{4}$ which effectively stated that the 'Parliament makes laws, the judiciary interpret them'. Adherents of the indeterminacy thesis therefore, attempted to demonstrate the inversion of the roles and functions of the state apparatus by highlighting the necessary contradictions of judges within the liberal paradigm and the 'systematic repression of the presence of these contradictions'. 5 Whatever the degree of this indeterminacy (and the degree is important) ${ }^{6}$ this particular critique attacked the almost naturalised presumption of the judicial role as mechanical, apolitical, declaratory and/or interpretive and replaced it with one that was ideological and rhetorical- 'crits therefore tend to take the rhetoric of law very seriously and examine its content carefully'?

This paper focuses on a particular exposition of one of CLS's claims, more commonly associated with Mark Kelman ${ }^{8}$ and less so associated to Kevät Nousiainen. ${ }^{9}$ Setting his sights on criminal law, Kelman highlights the arational choices ${ }^{10}$ in factual construction in which judges can either use narrow or broad time frames in which to locate a defendant's act- this subsequently effects the normative ascription of responsibility. Nousiainen similarly deploys the use of broad or narrow time frames in formulating her triad of 'text, time and reality construction', ${ }^{11}$ pushing further still by attempting to articulate the theory of time that informs the process of time framing in adjudication. Incredibly however, time frames, what Kelman says is part of the interpretive construction step in criminal law adjudication, 'goes virtually unexamined' ${ }^{12}$

Time frames, I will argue, actually bring together many of the underlying themes of both the ALR and CLS attacks on legal formalism. The position will be that time frames presuppose both the indeterminacy posited by Karl Lllewellyn's janus-faced doctrine of precedent ${ }^{13}$ and also the central claims of the CLS movement, particularly

\footnotetext{
4 [1982] 1 WLR 142 [157]

${ }^{5}$ Mark Kelman, A Guide to Critical Legal Studies (Harvard University Press, 1987) 3

${ }^{6}$ The indeterminacy thesis can roughly be divided into the strong thesis, which claims a radical indeterminacy of law, or the weak thesis, which states a modest indeterminacy. The degree of (in)determinacy lays overall claims to the very legitimacy of law and adjudication as a normative system. See also Ken Kress, 'Legal Indeterminacy’ (1989) 77,2 California Law Review

${ }^{7}$ Robert Gordon, 'Law and Ideology’ (1988) 3,1 Tikkun, 15

${ }^{8}$ Mark Kelman, 'Interpretive Construction in the Substantive Criminal Law' (1981) 33, 4 Stanford Law Review, 594

${ }^{9}$ Kevät Nousiainen, 'Time of Law, Time of Experience' in Jes Bjarup \& Mogens Blegvad (eds), Time, Law and Society: Edited

Proceedings of a Nordic Symposium at Sandbjerg Gods (Franz Steiner Verlag, 1994) 23- the reason why Nousiainen's paper is less so associated is because her argument is not framed within the context of legal indeterminacy

${ }^{10}$ Mark Kelman, 'Interpretive Construction in the Substantive Criminal Law' (1981) 33, 4 Stanford Law Review, 594

${ }^{11}$ Kevät Nousiainen, 'Time of Law, Time of Experience' in Jes Bjarup \& Mogens Blegvad (eds), Time, Law and Society: Edited

Proceedings of a Nordic Symposium at Sandbjerg Gods (Franz Steiner Verlag, 1994) 23

${ }^{12}$ Mark Kelman, 'Interpretive Construction in the Substantive Criminal Law' (1981) 33, 4 Stanford Law Review, 594-595

${ }^{13}$ Karl Llewellyn, The Bramble Bush (Oceana Publications, 1930) 76
} 
the contradictions between rules-standards and free-will-determinism that plague ${ }^{14}$ law and adjudication. I will argue therefore, that time frame indeterminacy has chronological priority, in that it underwrites the claims of indeterminacy central to ALR and CLS attacks on formalism.

Kelman and Nousiainen are also particularly interesting as retrospectively read, they appear to anticipate an interesting current in legal scholarship that explores the intersection of time, law and regulation. Arguably initiated by legal anthropologists such as Carol Greenhouse ${ }^{15}$ and David Engel, ${ }^{16}$ a series of papers have since been published from a symposium on Time, Law and Society in 1994, ${ }^{17}$ and a 2012 conference hosted by the MaxPlanck Institute for Social Anthropology entitled The Temporalities of Law. ${ }^{18}$ Finally, a newly formed research network that co-ordinated a 3-day workshop entitled Diagnosing Legal Temporalities ${ }^{19}$ with recent international conference in September 2016 has arguably signalled a critical juncture in legal scholarship, or a 'temporal turn in law'. ${ }^{20}$

The paper begins with a brief restatement of legal indeterminacy, relating the centrality of this critique primarily to the rule of law and theories of legitimacy as the prima facie reasons ${ }^{21}$ why the debate once commanded eminence in legal scholarship. This section will detail the central claims of CLS, as well as those of ALR, specifically the strict and loose variants of precedent authored by Karl Llewellyn.

The following section will turn toward the particular expressions of indeterminacy authored by Mark Kelman and Kevät Nousiainen. Common to both is that they describe theories of factual construction, or synoptic judgement, ${ }^{22}$ as contingent on either narrow or broad time frames. Absent some independent normative criterion, indeterminacy derives from the judicial choice of which time frames to adopt. With recourse to a few examples from case law,

\footnotetext{
${ }^{14}$ Many would reject the idea that law is, at worst, radically indeterminate. See also Ken Kress, 'Legal Indeterminacy’ (1989) 77,2 California Law Review, 285

${ }^{15}$ Carol Greenhouse, A Moment's Notice: Time Politics Across Cultures (Cornell University Press, 1996)

${ }^{16}$ David M. Engel, 'Law, Time and Community' (1987) 21, 4 Law and Society Review

${ }^{17}$ Jes Bjarup \& Mogens Blegvad (eds), Time, Law and Society: Edited Proceedings of a Nordic Symposium at Sandbjerg Gods (Franz Steiner Verlag, 1994)

${ }^{18}$ Keebet von Benda-Beckmann, 'Trust and the Temporalities of Law' (2014) 46, 1 The Journal of Legal Pluralism and Unofficial Law

${ }^{19}$ Emily Grabham, Doing Things with Time (University of Toronto Press, 2016) (Forthcoming)

${ }^{20}$ Mariana Valverde, Chronotopes of Law: Jurisdiction, Scale and Governance (Routledge, 2015) 37-43

${ }^{21}$ Ken Kress 'Legal Indeterminacy' (1989) 77, 2 California Law Review, 285

${ }^{22}$ Emmet T. Flood, 'Fact Construction and Judgement in Constitutional Adjudication' (1991) 100, 6 The Yale Law Journal, 1795
} 
time frame indeterminacy will then be located within the main contradictions of legal liberalism identified by the CLS literature and ALR's theories of precedent. The main position of the paper will be made here in that time frame indeterminacy actually underwrites the key claims of indeterminacy informing both CLS and ALR's attack on legal formalism- what is referred to as its chronological priority. Time frame indeterminacy illustrates, I will argue, the simultaneous (and thus contradictory) commitments to both free will and determinism in CLS thinking about law and adjudication, as well as illuminating the presence of both rigid rules and context-sensitive standards in legal norms. Further, time frame indeterminacy can provide another site of uncertainty in the interpretive variants of precedent. Time frame indeterminacy therefore, because of its chronological priority, is a more fundamental explanation for the phenomenon of indeterminacy in law.

The final section will briefly entertain the degree of such indeterminacy before stating its potential in light of an emerging interest in time and law.

\section{The Indeterminacy Thesis}

Traditional legal theory is based on the fundamental presumptions that require its proponents to find, or at least search for, determinate, objective and neutral decision making procedures which are grounded on rational, and therefore apolitical grounds. ${ }^{23}$ Such a theory contends that a legal rule or form of legal reasoning would constrain the choice of the rule applier. So for the Hartian positivist, the judge is constrained by rules that are etymologically connected to the Rule of Recognition of that jurisdiction (or the 8 desiderata for the Fullerian natural lawyer etc). Rules are traceable to stable and objectively verifiably criteria in a normatively closed system that extinguishes the possibility of judicial choice in deciding cases- and the law, so defined, will always provide one right answer.

The law is indeterminate therefore, to the extent that 'legal questions lack single right answers. In adjudication, law is indeterminate to the extent that authoritative legal materials and methods permit multiple outcomes and lawsuits'. ${ }^{24}$ If this claim holds, then the outcome of legal decisions are based, not on 'the rational reconstruction

\footnotetext{
${ }^{23}$ Joseph Singer, 'The Player and the Cards: Nihilism and Legal Theory' (1984) 94, 1 The Yale Law Journal, 8

${ }^{24}$ Ken Kress, 'Legal Indeterminacy’ (1989) 77, 2 California Law Review, 283
} 
of segments of law upon the basis of the judicial and statutory materials ${ }^{25}$ but instead from personal, political or institutional biases and 'the ideal of an impartial adjudicator applying and not making the law, can be unmasked as the exercise of naked power cloaking existing structures of power and hierarchy in a veil of inevitability or stability'. ${ }^{26}$ Law and adjudication cease to be understood as neutral but are instead mechanisms for creating and legitimating configurations of power, ${ }^{27} \mathrm{a}$ 'plastic medium of discourse that subtly conditions how we experience social life'. ${ }^{28}$

Another important component of the indeterminacy debate is that of indeterminacy's degree. Some concede that though indeterminacy exists it is, at worst, moderate, manageable and therefore in no way delegitimising to the enterprise of law. ${ }^{29}$ Others posit a more radical, or strong thesis, that presents the indeterminacy of law and adjudication as unstable ${ }^{30}$ though they warn against a nihilistic vision of law, with one instead based on conversation and responsibility. ${ }^{31}$ The varying degrees, say its adherents, primarily stem from an apparent essentialism that informs claims of linguistic determinacy. Critics state that terms in legal rules gather numerous known and unknown particulars under headings such as "vehicles," "punishment," "dogs", 32 and so the level of abstraction is conducive to indeterminacy. The Wittgenstinian approach, which calls into question the ability of an individual to fix any determinate meaning to a rule, ${ }^{33}$ supports the strong thesis by stating that 'no course of action can be determined by a rule because every course of action can be made to accord with the rule' ${ }^{34}$ The claim that legal rules include some actions but not others is not possible as the rule is 'always up for grabs'. ${ }^{35}$

“A judge faced with the legal rule: "apply $x$ to all things with this fact," must have a means of interpreting the rule in order to grasp the concept "x," and whenever something looks like "this" in order to follow it

\footnotetext{
${ }^{25}$ William Lucy, Understanding and Explaining Adjudication (Oxford University Press, 1999) 189

${ }^{26}$ Conor Casey, 'Legal Indeterminacy: Causes and Significance' (2015) 18 Trinity College Law Review, 47

${ }^{27}$ Joseph Singer, 'The Player and the Cards: Nihilism and Legal Theory' (1984) 94, 1 The Yale Law Journal, 7

${ }^{28}$ Robert Gordon, 'Law and Ideology' Tikkun vol 3, no 1 pp $16 \mathrm{~s}$

${ }^{29}$ Ken Kress, 'Legal Indeterminacy’ (1989) 77, 2 California Law Review

${ }^{30}$ Duncan Kennedy, 'Form and Substance in Private Law Adjudication' (1976) 89 Harvard Law Review; Joseph Singer, 'The Player and the Cards: Nihilism and Legal Theory' (1984) 94, 1 The Yale Law Journal

${ }^{31}$ Joseph Singer, 'The Player and the Cards: Nihilism and Legal Theory' (1984) 94, 1 The Yale Law Journal, 51

${ }^{32}$ Frederick Schauer, 'Formalism' (1988) 97, 4 The Yale Law Journal, 534

${ }^{33}$ Saul Kripke, Wittgenstein on Rules and Private Language: An Elementary Exposition (Harvard University Press, 1982)

${ }^{34}$ Conor Casey, 'Legal Indeterminacy: Causes and Significance' (2015) 18 Trinity College Law Review, 44

${ }^{35}$ Brian Leiter and Jules Coleman, 'Determinacy, Objectivity and Authority' (1993) 142, 2 University of Pennsylvania Law Review, 568
} 
correctly...Even if another rule is provided to govern the above rule, that rule itself must be re-interpreted ad infinitum, ${ }^{36}$

The rules of language are not comprehensive $e^{37}$ in that they cannot anticipate every possible factual situation ${ }^{38}$ and therefore the determination of something that looks like "this" undermines the correspondence theory of rule with fact. Because of the indeterminacy of legal language therefore, antonymous legal outcomes can be predicated on the same legal rules. Consider for example the case of Plessy v. Ferguson ${ }^{39}$ contra. Brown v. Board ${ }^{40}$ and their mutual reliance upon the US $14^{\text {th }}$ Equal Protection Amendment.

Though there have been sound refutations to the strong thesis ${ }^{41}$ even Hart's positivism accounts for interstitial legislating, resulting from the core and penumbra of meaning. Thus, if there is nothing constraining judges, they cease to be applying the law and are de facto legislators with their judgments shrouded in 'rational rhetoricism' ${ }^{42}$ hence the popular expression of describing the common law as 'pouring new wine into old bottles'. ${ }^{43}$

This other key question is why (in)determinacy is essential to the legal enterprise. The obvious reasons stem from the desirability to restrain arbitrary ${ }^{44}$ judicial power, predatory conduct ${ }^{45}$ or judicial tyranny ${ }^{46}$ and thus preventing judges from becoming law makers. But why are judicial law makers considered problematic? The diverse responses to this effectively present constitutional arguments that presume a particular normative configuration of the separation of powers and the roles of each branch of the state. The democratic and accountability deficit of

\footnotetext{
${ }^{36}$ Conor Casey, 'Legal Indeterminacy: Causes and Significance' (2015) 18 Trinity College Law Review, 45

${ }^{37}$ Joseph Singer, 'The Player and the Cards: Nihilism and Legal Theory' 94, 1 (1984) The Yale Law Journal, 14

${ }^{38}$ This is also developed by Alexandre Lefebvre in his rejection of the 'subsumptive theory of judgment'. See also Alexandre Lefebvre, The Image of Law: Deleuze, Bergson, Spinoza (Stanford University Press, 2008) 107-114

39163 U.S. 537

40347 U.S. 483

${ }^{41}$ Conor Casey tries to argue that elements of Wittgenstein have been overlooked that actually refute this strong thesis. See also Conor Casey, 'Legal Indeterminacy: Causes and Significance' (2015) 18 Trinity College Law Review

${ }^{42}$ Mark Kelman, 'Interpretive Construction in the Substantive Criminal Law' (1981) 33, 4 Stanford Law Review, 592

${ }^{43}$ Arthur R Hogue, Origins of the Common Law (Indiana, University Press, 1966) 11

${ }^{44}$ Singer makes a distinction between indeterminacy and arbitrariness. See also Joseph Singer, 'The Player and the Cards: Nihilism and Legal Theory' 94, 1 (1984) The Yale Law Journal, 20-22

${ }^{45}$ Joseph Singer, 'The Player and the Cards: Nihilism and Legal Theory' 94, 1 (1984) The Yale Law Journal, 50

${ }^{46}$ Mark Tushnet 'Following the Rules Laid down: A Critique of Interpretivism and Neutral Principles' (1983) 96, 4 Harvard Law Review, 785
} 
judges mean that states must commit to the ideal of judges as the appliers or declarers of law (though the question of contention becomes what constitutes 'application' or ‘declaration' of law).

Theoretically however, 'indeterminacy matters because legitimacy matters' ${ }^{47}$ Whatever the theory upon which the state legitimates itself (explicit/tacit consent, residence, fair play, a duty to uphold just institutions or the heterodoxy which is an amalgam of these theories $)^{48}$ judges should apply laws, acting as agents of the sovereign. Coercion ${ }^{49}$ by laws is only legitimate if the process of making/declaring/interpreting them are constrained by determinate legal rules and as such, provide a moral obligation to follow them.

As well as also protecting 'predictability, stability, efficiency, the elimination of error and of bias, and general consistency and coherence ${ }^{50}$ determinacy is perhaps more abstractly, and most significantly, important for upholding the rule of law. Though the concept of the rule of law has given rise to a 'rampant divergence of understandings ${ }^{\prime 51}$ (and more scathingly 'just another one of those self-congratulatory rhetorical devices that grace the public utterances of Anglo-American politicians') $)^{52}$ there are common articulations of both its substantive and procedural formulations. For example, Lord Bingham suggests that due process, human rights, accessibility of the law, the non-discretionary nature of judges are some of its salient features. ${ }^{53}$ Dicey's classic exposition firstly stated 'that no man is punishable or can lawfully be made to suffer in body or goods except for a distinct breach of law established in the ordinary legal manner before the ordinary courts of the land' ${ }^{54}$ Secondly, he cited 'that here, every man, whatever be his rank or condition, is subject to the ordinary law of the realm and amenable to the jurisdiction of the ordinary tribunals'. ${ }^{55}$ Finally, Dicey attributes the manifestations of the rule of law to the incrementalism of the common law. ${ }^{56}$ These components of the rule of law would appear to be compromised were it not for the claims that adherents of legal determinacy make. However, Peter Singer says the claim of determinacy and the rule of law are both mutual and ideological in making judges appear to be rule appliers rather

\footnotetext{
${ }^{47}$ Ken Kress, 'Legal Indeterminacy' (1989) 77, 2 California Law Review, 285

${ }^{48}$ Ken Kress challenges the claim that moderate indeterminacy, having disposed of radical indeterminacy, undermines legitimacy by using a 'heterodox' understanding of legitimacy. See also Ken Kress, 'Legal Indeterminacy' (1989) 77, 2 California Law Review, 285

${ }^{49}$ Duncan Kennedy, 'Legal Formalism' (1973) 2, 2 The Journal of Legal Studies, 352

${ }^{50}$ William Twinning and David Myers, 'How to Do Things with Rules' (Cambridge University Press, 2012) 290

${ }^{51}$ Brian Tamanaha, On the Rule of Law (Cambridge University Press, 2004) 3

52 Judith Shklar, 'Political Theory and the Rule of Law', in A Hutchinson and P Monahan (eds.), The Rule of Law: Ideal or Ideology

(Carswell, 1987) 1

${ }^{53}$ Tom Bingham, 'The Rule of Law' (Penguin Books, 2010)

${ }^{54}$ A V Dicey, 'An Introduction to the Study of the Law of the Constitution' (1885, $9^{\text {th }}$ edition, Macmillan, 1945) 188

${ }^{55}$ A V Dicey, 'An Introduction to the Study of the Law of the Constitution' (1885, $9^{\text {th }}$ edition, Macmillan, 1945) 193

${ }^{56}$ A V Dicey, 'An Introduction to the Study of the Law of the Constitution' $\left(1885,9^{\text {th }}\right.$ edition, Macmillan, 1945) 195
} 
than rule makers. ${ }^{57}$ Indeed, 'if traditional legal theorists are correct about the importance of determinacy to the rule of law, then- by their own criteria- the rule of law has never existed anywhere. This is the real bite of the critique'. ${ }^{58}$

\section{Critical Legal Studies and the contradictions of legal liberalism}

CLS levelled its attacks against 'the crucial structural characteristics of mainstream legal thought as examples of something called "liberalism". ${ }^{59}$ Legal liberalism was a catch all term ${ }^{60}$ that encompassed the writings of contemporary positivists, natural lawyers and interpretivists like Hart, Fuller and Dworkin. Kelman describes legal liberalism as beset by 'internal contradictions and by systematic repression of the presence of these contradictions. ${ }^{91}$ These contradictions were not merely competing conceptions of the good which were 'artfully

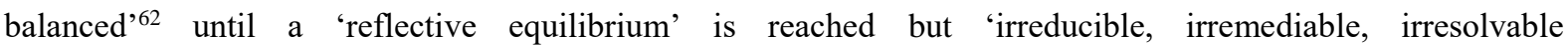
conflict...critics...identify a contradiction in liberal legal thought, a set of paired rhetorical arguments that both resolve cases in opposite, incompatible ways and correspond to distinct visions of human nature and human fulfilment' ${ }^{63}$

There are 3 sets of paired rhetorical arguments that form the central tenets of the CLS attack on legal liberalism.

The first is between 'a commitment to mechanically applicable rules as the appropriate form of resolving disputes... and a commitment to situation-sensitive, ad-hoc standards' ${ }^{64}$ Duncan Kennedy describes this as the ‘degree of formal realizability' of legal norms:

\footnotetext{
${ }^{57}$ Joseph Singer, 'The Player and the Cards: Nihilism and Legal Theory' 94, 1 (1984) The Yale Law Journal, 12

${ }^{58}$ Joseph Singer, 'The Player and the Cards: Nihilism and Legal Theory' 94, 1 (1984) The Yale Law Journal, 14; Interestingly, in commenting on the controversial US Supreme Court case Bush v. Gore 531 US 98 (2000) which decided who had won the 2000 presidential election, Jeremy Waldron highlighted how the rule of law had been invoked by both sides, and therefore meaning little more than 'hooray for our side'. See also Jeremy Waldron, 'Is the Rule of Law and Essentially Contested Concept (in Florida), in R Bellamy (ed.), The Rule of Law and Separation of Powers (Ashgate, 2005) 119

${ }^{59}$ Mark Kelman, A Guide to Critical Legal Studies (Harvard University Press, 1987), 2

${ }^{60}$ Kelman outlines that liberals include 'deontological rights theorists and those who are openly utilitarian are linked; anarchic libertarians and New Deal apologists are treated as forming the same school. See also A Guide to Critical Legal Studies (Harvard University Press, 1987), 3

${ }^{61}$ Mark Kelman, A Guide to Critical Legal Studies (Harvard University Press, 1987) 2

${ }^{62}$ Mark Kelman, A Guide to Critical Legal Studies (Harvard University Press, 1987) 3

${ }^{63}$ Mark Kelman, A Guide to Critical Legal Studies (Harvard University Press, 1987) 3

${ }^{64}$ Mark Kelman, A Guide to Critical Legal Studies (Harvard University Press, 1987) Chapter 1. This is also discussed in the Legal Realist school in determining whether rules are to control or to guide. See also Karl Llewellyn, The Common Law Tradition (Brown \& Company, 1960) $178-180$
} 
"The extreme of formal realizability is a directive to an official that requires him to respond to the presence together of each of a list of easily distinguishable factual aspects by intervening in a determinate way. Ihering used the determination of legal capacity by sole reference to age as a prime example of formally realizable definition of liability...At the opposite pole from a formally realizable rule is a standard...A standard refers directly to one of the substantive objectives of the legal order. Some examples are good faith, due care, unconscionability, unjust enrichment, and reasonableness". ${ }^{65}$

I would claim that we can infact identify 2 types of standards. One type mitigates the strength of the correspondence theory underlying legal norms. For example, the age to vote in the UK General Election is governed by the Representation of the People Act $1969^{66}$ which states that British Citizens with legal capacity must be at least 18 to vote. The purpose of this legislation is most likely to ensure that those who are considered mature enough, are entitled to vote. However, arguments could be made that 16 or 17 year olds, who are already allowed to leave school, get married or joined the armed forces, ought to also be entrusted with the right to vote; while many over 18 may in fact lack maturity and it may not be unreasonable to suggest that one day, such arguments are accepted. The other type of standards include the more obvious 'objectives of a the legal order', that Kennedy refers to, such as legality, procedural fairness, reasonableness and proportionality. Standards exist therefore, either as objectives of legal orders or as mitigating the strength of the correspondence theory underlying rigid legal rules.

The choice of form for a judge is symptomatic, according to Kennedy, of a deeper antagonism between apposite political visions. Adherents of the pro-rules stance reify self-reliance and individualism while the pro-standards camp are correspondent with altruism - this is what Kennedy famously describes as the fundamental contradiction. ${ }^{67}$ There are vices and virtues ${ }^{68}$ of a legal norms' formal realizability but importantly, indeterminacy derives from the absence of an independent criterion or metaprinciple that selects either one of these forms. ${ }^{69}$

\footnotetext{
${ }^{65}$ Duncan Kennedy, 'Form and Substance in Private Law Adjudication' (1976) 89 Harvard Law Review, 1687-1688 ${ }^{66} \mathrm{XXX}$

${ }^{67}$ Duncan Kennedy, 'Form and Substance in Private Law Adjudication' (1976) 89 Harvard Law Review, 1712

${ }^{68}$ M D A Freeman, Introduction to Jurisprudence $\left(8^{\text {th }}\right.$ ed. Sweet \& Maxwell, 2008) 1211

${ }^{69}$ Is this conflict over-emphasised? See also M D A Freeman, Introduction to Jurisprudence ( ${ }^{\text {th }}$ ed. Sweet \& Maxwell, 2008) $1212-1213$
} 
The second pair of rhetorical arguments of legal liberalism is that of:

'the contradiction between a commitment to the traditional liberal notion of values or desires as arbitrary, subjective, individual and individuating while facts or reason are objective and universal and a commitment to the ideal that we can know social and ethical truths objectively...or to the hope that one can transcend the usual distinction between subjective and objective in seeking moral truth' ${ }^{70}$

Popularised by one of the early seminal texts of CLS ${ }^{71}$ this claim identifies 'liberalism positivists method failing to meet its normative needs, the difficulties it confronts when applying empirical methodology to human desire'. ${ }^{72}$ As liberal theory claims no conception of the good and is merely a system for negotiating these private desires, indeterminacy emanates from establishing the aggregating calculus for accommodating these subjective desires.

The third and final of the pair of contradictions is the latent free will-determinist contradictions that underpin liberal legal discourse. ${ }^{73}$

'Intentionalist discourse pictures human action in phenomenological, forward-looking, free-willoriented terms, emphasizing the indeterminacy of action and, correlatively, the ethical responsibilities of actors. Determinist discourse pictures conduct in structuralist, back-ward-regarding, amoral terms, holding conduct as simply a last event we focus on in a chain of connected events so predetermined as to merit neither respect nor condemnation' ${ }^{74}$

\footnotetext{
${ }^{70}$ Mark Kelman, A Guide to Critical Legal Studies (Harvard University Press, 1987) Chapter 2

${ }^{71}$ Roberto Unger, Knowledge and Politics (Free Press, 1974)

${ }^{72}$ Mark Kelman, A Guide to Critical Legal Studies (Harvard University Press, 1987) 73

${ }^{73}$ Mark Kelman, A Guide to Critical Legal Studies (Harvard University Press, 1987) Chapter 3

${ }^{74}$ Mark Kelman, A Guide to Critical Legal Studies (Harvard University Press, 1987) 86
} 
A good example would be to determine which facts are relevant in an apparent murder indictment, either the intent and act of a woman that kills her husband, or placing the mens rea and actus reus of the same woman as the last event in a series of events that begin from her being a victim of sustained physical violence. Indeterminacy derives from the choice of these opposing correlates.

\section{American Legal Realism and the indeterminacy of precedent}

Karl Llewellyn, one of the progenitors of the US Legal Realist movement, describes indeterminacy as the differential readings of precedent. He begins by outlining the normative arguments for precedent, one of which is 'to provide a new official in his inexperience with the accumulated experience of his predecessors' ${ }^{75}$ However, reading precedent 'is not like a hunt for buried treasure, but typically involves an element of choice from a range of possibilities ${ }^{76}$ and can be read in either its strict or loose variants. The strict or orthodox view is the examination of the ratio of a previous case such that it can only be binding if, in the current case, those very same facts obtain. To use Llewellyn's colourful phrasing, 'this rule holds only of redheaded Walpoles in pale magenta cars' ${ }^{77}$ In effect, this is writ for overruling unwelcome precedents while paying lip service to precedential obedience. The loose view of precedent turns on abstracting the key elements of the precedent, claiming that if all or even if just some of the points obtain in the case at hand, it is bound. ${ }^{78}$ At its extreme end, this may even include reading into obiter statements or language found in past opinions as binding. Indeed, 'sometimes judges and other interpreters lay great stress on the particular words used in such judicial formulations' ${ }^{79}$ The loose approach is thus 'a device for capitalizing on welcome precedents'. ${ }^{80}$

Because of these variant (though not necessarily radically so) ${ }^{81}$ styles, ${ }^{82}$ Llewellyn suggests that one can predict very little from just the rules alone but one 'must turn, for purposes of prediction, to the reactions of the judges to

\footnotetext{
${ }^{75}$ Karl Llewellyn, The Bramble Bush (Oceana Publications, 1930), 71

${ }^{76}$ William Twinning and David Myers, 'How to Do Things with Rules' (Cambridge University Press, 2012) 306

${ }^{77}$ Karl Llewellyn, The Bramble Bush (Oceana Publications, 1930), 73

${ }^{78}$ Karl Llewellyn, The Bramble Bush (Oceana Publications, 1930), 73

${ }^{79}$ William Twinning and David Myers, 'How to Do Things with Rules' (Cambridge University Press, 2012) 278

${ }^{80}$ Karl Llewellyn, The Bramble Bush (Oceana Publications, 1930), 74

${ }^{81}$ William Twinning and David Myers, 'How to Do Things with Rules' (Cambridge University Press, 2012) 306

82 Though this may be ripe for radical indeterminacy, Llewellyn explain that there are certain stabilising 'cluster of factors' such as 'lawconditioned officials', known doctrinal techniques, the arguments of council etc. See also Karl Llewellyn, The Common Law Tradition
} 
the facts and to the life around them' ${ }^{83}$ Both are equally legitimate styles of reading interpretation and lend ammunition to one of the perennial axioms of the realist movement that what counted as law is what judges did in particular cases. ${ }^{84}$

In essence, what these differential readings of precedent boil down to is which facts are relevant and the level of abstraction of those relevant facts. Ken Kress puts it that 'the precedential techniques must be restricted to ensure that only relevant facts appear in the rules they generate or that the rules are defensible or justified. In effect a theory of which facts are relevant would be a theory of common law adjudication' ${ }^{85}$

\section{Time-Frame Indeterminacy}

Brian Leiter, in his paper Legal Indeterminacy, identifies four components of what he calls the Class of Legal Reasons one of which is the legitimate interpretive operations on the facts of record in order to generate facts of legal significance. ${ }^{86}$ The claim here is that time frames determine, in part, facts of legal significance. By time frame indeterminacy, it is generally meant that the determination of facts in adjudication is, in part, contingent upon the adoption of either narrow or broad time frames, the selection of which is itself not determined by any independent normative criterion. Thus the unrestrained selection of time frames is indicative of either a moral or political stance taken by the judges.

\section{Unconscious interpretive constructs in criminal law}

Mark Kelman, ${ }^{87}$ focussing on criminal law adjudication, ties together temporality and factual construction, beginning with the claim that legal argument proceeds in two stages- interpretive construction and rational

(Brown \& Company, 1960); he also says that certain strict readings of precedent would be absurd such as making the distinction on the basis of hair colour. See also Ken Kress, 'Legal Indeterminacy' (1989) 77, 2 California Law Review) 299

${ }^{83}$ Karl Llewellyn, The Bramble Bush (Oceana Publications, 1930), 75

${ }^{84}$ Oliver Wendell Holmes, The Common Law (The Lawbook Exchange, 1881)

${ }^{85}$ Ken Kress, 'Legal Indeterminacy' (1989) 77, 2 California Law Review) 300-301

${ }^{86}$ Brian Leiter, 'Legal Indeterminacy' (1995) 1 Legal Theory 481

${ }^{87}$ Mark Kelman, 'Interpretive Construction in the Substantive Criminal Law' (1981) 33, 4 Stanford Law Review, 591 
rhetoricism, the first of which is composed of four unconscious elements. ${ }^{88}$ The first of these unconscious elements include the use of narrow or broad time frames where adjudication may 'incorporate facts about events preceding or post-dating the criminal incident. An interpreter however, can readily focus solely on the isolated criminal incident, as if all we can learn of value in assessing culpability that can be seen with that narrower time focus' ${ }^{89}$ A simple example, demonstrated by Alan Norrie, ${ }^{90}$ is of an old American case of State v Preslar. ${ }^{91}$ A woman, after having being beaten by her husband, left the family home for her father's with her child. Some distance from her house, she rested and decided to continue the following morning but died of exposure. The court argued that she had exposed herself without necessity and was 'fully voluntary'. Had the courts applied a broader time frame they may have connected the woman's act to the ill-treatment from her husband and perceived it as a constituted act of necessary self-preservation.

Second of the constructs, related to the first, is the apportioning of disjoined or unified accounts which may force us to look beyond an isolated incident say if a defendant made a decision at an earlier moment to act criminally; 'is a negligent decision to kill followed by an intentional killing a negligent or intentional act? Is the person who misses X and shoots Y someone who commits two crimes- attempted murder of X plus, say, reckless homicide of Y- or one crime- an intentional murder of the person?'92 Thirdly, broad or narrow views of intent which reflect upon whether, in the commission of a crime, a person thinks singularly about each and every aspect in the execution of the criminal act. Finally, broad or narrow views of the defendant determine whether the defendant's history may incorporate mitigating circumstances, displacing the deracinated, 'rational and so the legally competent...classic contractor' 93 with a legal persons who is constituted and situated. ${ }^{94}$ Norrie adds that the paradigmatic rational legal subject ${ }^{95}$ loses its special character when a broader time-frame is adopted ${ }^{96}$ with James Boyle describing the example of the battered woman defence as an instance of the 'temporal stretching of the legal subject' 97

\footnotetext{
${ }^{88}$ Benjamin Cardozo also accounts for the 'subconscious element in the Judicial Process' as the forces of 'likes and dislikes, the predilections and the prejudices, the complex of instincts and emotions and habit and convictions, which make man, whether he be litigant or judge.' See also Benjamin Cardozo, The Nature of the Judicial Process (Yale University Press, 1921) 167-180

${ }^{89}$ Mark Kelman, 'Interpretive Construction in the Substantive Criminal Law' (1981) 33, 4 Stanford Law Review, 594

${ }^{90}$ Alan Norrie, Crime, Reason and History: A Critical Introduction to Criminal Law (Cambridge University Press, 2011) 141

91 (1885) 48 NC 41718

92 Mark Kelman, 'Interpretive Construction in the Substantive Criminal Law' (1981) 33, 4 Stanford Law Review ,595

${ }^{93}$ Ngaire Naffine, 'Who are Law's Persons? From Cheshire Cats to Responsible Subjects' (2003) Modern Law Review, 362

${ }^{94}$ Steven L. Winter, 'Indeterminacy and Incommensurability in Constitutional Law' (1990) 78 California Law Review, 1486

${ }^{95}$ Ngaire Naffine, Law's Meaning of Life: Philosophy, Religion, Darwin and the Legal Person (Hart Publishing, 2009), 64-65

${ }^{96}$ Alan Norrie, Crime, Reason and History: A Critical Introduction to Criminal Law (Cambridge University Press, 2011) 137-141

${ }^{97}$ James Boyle, 'Is Subjectivity possible? The Postmodern Subject in Legal Theory' (1991) 62 University of Colorado Law Review, 522
} 
Kelman specifically discusses time frame indeterminacy within the context of the free will-determinist tensions of legal liberalism. The criminal law, he claims, tends to adopt narrow time frames and, to quote Lindsay Farmer's reading of Kelman, has particular political implications, buttressing a particular view of free will, since it leads us to ignore earlier decisions or actions that could have an impact on our understanding of how free or determined a particular act actually was... shaped by political considerations and served certain social and class interests' ${ }^{98}$

\section{$\underline{\text { Reality Construction, text and time }}$}

Kevät Nousiainen's paper, Time of Law-Time of Experience, like Kelman, similarly relates temporality with fact construction. She argues that time is ontologically and epistemologically ${ }^{99}$ involved in the most basic questions of law and attempts to reconstruct temporality from the view of the action subject, suggesting that adjudication involves an interesting temporal challenge of being ex post while attempting to reconstruct the view of the action subject ex ante. Thus subjective time, Nousiainen cites, is operative alongside a universally accepted conception of time, and both inform the law. She thus establishes the triad of 'reality construction, text, time'.

The triad offers a clear description of how temporality conditions adjudication's fact construction. Adjudication will utilise broad or narrow time frames, wherein the broad time-frame considers incidents as constitutive of a unified whole, and the narrow as singular and disconnected- similar to that of Kelman's 4 interpretive constructs. She ventures into another direction, proceeding to develop a phenomenological conception of time of the action subject with recourse to Bergson's theory of time, durée, as experiential time, and his critique of Kant's concept of time, apportioned as legal time. She uses Bergsonian time to suggest that changes and subsequent measurement of experience are impossible as one cannot 'measure differences in experience'. However, Kant's spatialisation of real time qua durée delineates experience to create narrow or broad time frames for legal analysis. Once again, she also uses the cases of Battered Woman Syndrome and the choice of time frames adjudication employs in determining culpability.

\footnotetext{
${ }^{98}$ Lindsay Farmer, 'Time and Space in Criminal Law' (2010) 13, 2 New Criminal Law Review: An International and Interdisciplinary Journal, 340

${ }_{99}^{99}$ Kevät Nousiainen, 'Time of Law, Time of Experience' in Jes Bjarup \& Mogens Blegvad (eds), Time, Law and Society: Edited

Proceedings of a Nordic Symposium at Sandbjerg Gods (Franz Steiner Verlag, 1994) 23
} 
Though her focus involves exploring what theory of time is responsible for fact construction rather than entertaining the consequences of time frames for the determinacy of law, she and Kelman are analogous. According to both Nousiainen and Kelman therefore, absent some independent or 'transcendental rule' to determine which time frames to adopt, the law is indeterminate.

\section{Time Frame Indeterminacy at work}

A clear example ${ }^{100}$ of time frame indeterminacy involves the old provocation defence in the case of $R v$. Ahluwalia ${ }^{101}$ and $R$ v. Baillie (John Dickie). ${ }^{102}$ In determining the first limb of the defence 'sudden and temporary loss of self-control ${ }^{103}$ the courts factual construction used contrastingly narrow and broad time frames respectively. In the case of Ahluwalia, recalling that she had suffered horrendous domestic violence over several years, the courts were unwilling to entertain a lapse of time between the most recent bout of violence ('the provocation') and the killing of her husband. The appellant unsuccessfully tried to convince the courts of the 'the slow burn' approach as a justification for the lapse of time, which would have necessarily required the adoption of a broad time frame. Lord Taylor CJ stated that 'the defence is concerned with the actions of an individual who is not, at the moment when he or she acts violently, master of his or her own mind'. ${ }^{104}$ Contrastingly in the Baillie case, which involved a man who upon hearing that his son had been threatened by a drug dealer and then set off for the drug dealer's house, the courts here did adopt a broad time frame such that the lapse of time amounted to a sudden and temporary loss of self-control. To quote Lord Henry J, 'the judge ${ }^{105}$ clearly expressed the view that in her judgment this was not a case of provocation because any sudden or temporary loss of self-control must have ceased by the time of the fatal act...it seems to us that that approach is too austere an approach'. ${ }^{106}$

\footnotetext{
${ }^{100}$ Reference to time frames are almost never explicit and requires creative reading of the facts to determine when broad or narrow time frames are engaged. See also section Time Frame Indeterminacy and precendent

${ }^{101} R$ v. Ahluwalia [1993] 96 Cr. App. R. 31

${ }^{102}$ [1995] 2 Cr. App. R

${ }^{103} R v$ Duffy [1949] 1 AER 932

${ }^{104} R$ v. Ahluwalia [1993] 96 Cr. App. R. 31 [138] emphasis added

${ }^{105}$ Referring to the trial judge

${ }^{106} R$ v. Baillie (John Dickie) [1995] 2 Cr. App. R [37]
} 
There are a handful of points we can make about Kelman and Nousiainen's summation of time frame indeterminacy. One is that the tension between narrow and broad time frames have the possibility to introduce facts which potentially begin ab aeterno. If, for example, the contradiction in a murder indictment is between a 'narrow time frame' that sees a defendant is charged and convicted with murder and a 'broad time frame' that moves beyond the mens rea to include a qualifying trigger in the loss of self-control, why ought adjudication to stop there? This is a point to which I shall return to shortly but it should be noted at this juncture that this appears to claim a strong degree of indeterminacy in the use of time frames. The second point to make is that time frame analysis, according to Kelman, is a precursor to legal analysis ${ }^{107}$ and he adds that these constructs are 'sometimes unconscious techniques of sorting out legal material'. ${ }^{108}$ This is a particularly salient point to which I shall now turn- that time frame indeterminacy underwrites many of the central claims of legal indeterminacy.

\section{The Chronological Priority of Time Frame Indeterminacy}

Common to both Kelman and Nousiainen is that they claim theories of factual construction are, in part, contingent upon either the narrow or broad time frames adopted in adjudication. Absent some independent normative criterion or metaprinciple, indeterminacy derives from the judicial choice of which time frames to adopt.

The central claim of the paper is that time frame indeterminacy provides a more fundamental explanation for the phenomenon of indeterminacy more generally, and in fact presupposes many of the contradictions identified in the CLS and ALR literature. I will begin firstly with illustrating how time frame indeterminacy presupposes the simultaneous commitments to free will-determinism and rules-standards which are central to the CLS attacks on legal liberalism. I will then move onto demonstrating how time frame indeterminacy can supplement Llewellyn's strict and loose versions of precedent.

\footnotetext{
107 This is also mentioned in Freeman's discussion of the article. See also M D A Freeman, Introduction to Jurisprudence $\left(8^{\text {th }}\right.$ ed. Sweet \& Maxwell, 2008) 1214

${ }^{108}$ Mark Kelman, 'Interpretive Construction in the Substantive Criminal Law' (1981) 33, 4 Stanford Law Review, 592: emphasis added
} 
Before that however, I want to explain the chronological priority of time frame indeterminacy in adjudication. By chronological priority, I mean to say that the time frames adopted by judges precede what Kelman refers to as the second stage of (criminal law) adjudication, rational rhetoricism- 'distinguishing and analysing cases, applying familiar policies to unobvious fact patterns, and emphasizing the degree to which we can rely on the least controversial underlying values' ${ }^{109}$ Read in one way, it is in fact time frame indeterminacy which bases the different pairs of rhetorical arguments that form the central claims of legal indeterminacy in CLS and the strictloose readings of precedent in ALR. The claim of chronological priority is supported by Kelman when he states that it 'undercuts the rationality of the latter [rhetorical stage]'. ${ }^{110}$ The finesse and sophistication of legal rhetoricism attempts to present legal decision making as coherent, predictable and certain and is therefore falsely elevated so that people 'fail to see the interpretive construction that makes wise posturing possible'. ${ }^{111}$ Legal norms don't subsume ${ }^{112}$ or correspond to facts out there, but are determined, before any interpretive legal analysis takes place, through the use of time frames. The chronological priority of time frame indeterminacy was perhaps not as significantly recognised (and thus elevated in legal argument) by Kelman and others but the following sections attempt to explain and accentuate its importance as presupposing the claims of CLS and ALR indeterminacy.

\section{Time Frame Indeterminacy and the central claims of CLS}

The argument now will try to explain how time frame indeterminacy is chronologically prior to the central claims of indeterminacy in CLS and ALR. Kelman actually locates time frame indeterminacy squarely within the paired rhetorical arguments of free-will and determinism. Narrow time frames reinforce the free will paradigm and 'fends out' the undertaking of determinist analysis concomitant with the adoption of broader time frames. Kelman is clear therefore that time frame indeterminacy, the umbrella term for his 4 subconscious interpretive constructs,

\footnotetext{
${ }^{109}$ Mark Kelman, 'Interpretive Construction in the Substantive Criminal Law' (1981) 33, 4 Stanford Law Review, 592

${ }^{110}$ Mark Kelman, 'Interpretive Construction in the Substantive Criminal Law' (1981) 33, 4 Stanford Law Review, 592

${ }^{111}$ Mark Kelman, 'Interpretive Construction in the Substantive Criminal Law' (1981) 33, 4 Stanford Law Review, 592

${ }^{112}$ Alexandre Lefebvre, The Image of Law: Deleuze, Bergson, Spinoza (Stanford University Press, 2008) 13
} 
logically precedes the rational rhetoricism stage of substantive criminal law adjudication. Therefore, no further work needs to be done on the claim that time frame indeterminacy is chronologically prior to this particular claim of CLS indeterminacy.

However, I intend to extend the claim of the chronological priority of time frame indeterminacy by also arguing that it presupposes another of CLS's central claims to indeterminacy, that of the tension between rules and standards as different forms of legal directives. The differences between rules and standards (either as 'objectives of legal orders' or as mitigating the strength of the correspondence theory underlying rigid legal rules) pertain to the level in which they constrain judges. We can understand legal directives as having "two parts: a "trigger" that identifies some phenomenon and a "response" that requires or authorizes a legal consequence when that phenomenon is present'. ${ }^{113}$ Rules claim that, once the facts ('some phenomenon') are established ('trigger'), there application is clear (producing the 'response'). ${ }^{114}$ Contrastingly, standards allow some discretion to determine when the facts are established ('some phenomenon'), for example in determining 'reasonableness' or 'proportionality' or by mitigating the strength of the correspondence theory of rigid legal rules. Returning briefly to the example of enfranchisement in the UK, the statute clearly identifies a hard empirical trigger, ${ }^{115}$ (18 years of age) and consequently a clear response (enfranchisement). However, it is not completely inconceivable that an entirely new factual situation ('some phenomenon') may present itself which would warrant exception to this rule ('response') and this is what we mean when we say standards are situation sensitive- they incorporate other facts. Thus the 'bright line rule' for 18 years of age becomes a 'flexible standard' ${ }^{116}$ with the reception of new facts. That a 16 year old is allowed to leave school, get married or join the armed forces (or other examples of 'maturity/competence' as the underlying purpose of the statute) may warrant an exception to the seemingly hard rule, rendering it a standard. Joseph Singer describes the oscillation between rules and standards as the absence of consistency in legal norms such that the line between rules and exceptions can be moved. ${ }^{117}$ The tendency of exceptions being established from legal norms, emerge from the incorporation of other facts- thus they are more standard-like.

\footnotetext{
${ }^{113}$ Pierre J. Schlag, Rules and Standards (1985) 33 UCLA Law Review, 2

${ }^{114}$ Mark Kelman, A Guide to Critical Legal Studies (Harvard University Press, 1987) 15

115 Pierre J. Schlag, Rules and Standards (1985) 33 UCLA Law Review, 2

${ }^{116}$ Pierre J. Schlag, Rules and Standards (1985) 33 UCLA Law Review, 1

${ }^{117}$ Joseph Singer, 'The Player and the Cards: Nihilism and Legal Theory' 94, 1 (1984) The Yale Law Journal, 16
} 
Indeed, we know of many examples in which judges have established exceptions to seemingly hard and fast rulelike forms, thus rendering them situation-sensitive like standards. ${ }^{118}$ In contract, the determination of when a contract is formed can either operate on a rule-like form that obligations are not engaged unless there has been an offer and explicit acceptance (either through promise or performance); or it can operate as a standard-like form in that 'once a party begins to negotiate with another party, she has taken on an obligation of good faith dealing and must compensate a party damaged by the failure to act in good faith'. ${ }^{119}$ Another example confronting criminal law, is that of when inchoate crimes ought to be punishable. The rule-like solution is that the act is merely preparatory and not criminal until the defendant has taken the last possible step in his control to cause the proscribed harm; and the standard-like solution is that the act is merely preparatory and not criminal 'until he has taken the harder-to-define substantial step that strongly corroborates his intent to commit the crime'. ${ }^{120}$

Elements of what Kelman says in his 1981 paper may, at first, seem underwhelming, but appear to support the claim that time frame indeterminacy also underwrites the tension, not just between free will-determinism, but between rules and standards. The 'arational' interpretive constructions that precede the rational rhetoricism stage, are not just about how the factual situation is construed (with either broad or narrow time frames) but importantly 'the way we frame the possible rules to handle the situation'. ${ }^{121}$ So a legal norm's degree of formal realizability is conditioned on the time frames adopted. How is this so?

We may understand rule forms as under-inclusive of factual possibilities and standard forms as over-inclusive of factual possibilities. 'Some phenomenon' (as Schlag describes it as) will determine how (as Kelman phrases it) we frame the possible rule- either as a standard (as either objectives of legal orders or mitigating the correspondence theory of rigid rules) or as a rule, which will then trigger a response. This is what Kelman states, and this paper understands as, the chronological priority of time frame indeterminacy. 'Some phenomenon'

\footnotetext{
${ }^{118} R$ v. $R$ [1991] 3 WLR 767 (in which the matrimonial exception to rape, was reversed without legislation). Lord Keith's comments were particularly illuminating:

'It may be taken that the proposition was generally regarded as an accurate statement of the common law of England. The common law is, however, capable of evolving in the light of changing social, economic and cultural developments. Hale's proposition reflected the state of affairs in these respects at the time it was enunciated. Since then the status of women, and particularly of married women, has changed out of all recognition in various ways which are very familiar and upon which it is unnecessary to go into detail...In modern times any reasonable person must regard that conception as quite unacceptable.'

${ }^{119}$ Mark Kelman, A Guide to Critical Legal Studies (Harvard University Press, 1987) 18

${ }^{120}$ Mark Kelman, A Guide to Critical Legal Studies (Harvard University Press, 1987) 26

${ }^{121}$ Mark Kelman, 'Interpretive Construction in the Substantive Criminal Law' (1981) 33, 4 Stanford Law Review, 592
} 
describes the facts or more accurately, the time frames, adopted by the judges. We can further explore this by describing legal norms as either sensed or senseless and once again use the example of enfranchisement. If a legal norm is sensed ('rule'), it means that the way they are applied in 'real-life situations' is to subsume the factual situation into a pre-ordained category as if the legal norm had already anticipated it- the exclusive presence (ignoring everything else) of the fact that $x$ is 17 , renders them ineligible to vote. 18 years of age constitutes the age of enfranchisement and everything else, which may demonstrate to the contrary the purpose of the statute (maturity/competence) is irrelevant for the purposes of law. Senseless legal norms ('standard') on the other hand, can be tailored to a factual situation that it sees as unique, rather than as a particularisation of a general rule. With senseless norms 'what judges do, therefore, is provide a sense for the rule, which is to say that a judgment creates a rule insofar as it connects together the old form (tradition, the rule) and a new content (the reasons provided for the rule)'. ${ }^{122}$ A 17 year-old may demonstrate exceptional maturity through previous military service (incorporated through the use of a broad time frame), or may have been born on a leap year.

Importantly, the formal realizability of the legal norm is contingent on the time frames adopted. For example, broader time frames include more remote causal facts but may also include into the factual situation, particular elements of the legal subject's history or their milieus (as one of Kelman's interpretive constructs states). This in turn, will then determine the formal realizability of the legal norm; either as a rule or standard. Alan Norrie offers a point of departure in which to expand upon the notion of broader time frames, not just to include more remote causes but also conditions or what he calls 'deeper causes'. To help illustrate this point, Norrie refers to the Scarman Report, published in 1981 following the Brixton Riots and quotes Lord Scarman saying 'deeper causes undoubtedly existed, and must be probed: but the immediate cause of Saturday's events was a spontaneous combustion set off by the spark of one particular incident'. ${ }^{123}$ Norrie then goes on to analyse the report:

\footnotetext{
'Which factor 'makes the difference', the 'deeper causes' or the 'immediate cause'? If those 'deeper causes' (relating to poor social environment, racial discrimination, police harassment) are part of the 'normal conditions of life in the late twentieth-century, are they for that reason excluded from our account of what caused the riot? It would perhaps be convenient for the law, with its emphasis on the individual,
}

\footnotetext{
122 Alexandre Lefebvre, The Image of Law: Deleuze, Bergson, Spinoza (Stanford University Press, 2008) 102

${ }^{123}$ Lord Scarman, The Brixton Disorders 10-12 April 1981 Report Command 8932
} 
if they were. Elsewhere in his report, Lord Scarman did draw a distinction between the 'causes' and the 'conditions' of the riots $(1981,16)$. This was shortly before he argued that the conditions of young black people cannot exclude their guilt for grave criminal offences which, as causal agents, they have committed'. ${ }^{124}$

The definition of time frames therefore could be enriched to also include 'deeper causes' as well as the 'immediate causes'. However, a point was made earlier that indeterminacy derivative from time frames has the possibility to construct factual situations of relevancy which begin ab aeterno. Could this expanded notion of broad time frames also include, among other things, socio-economic duress, colonialism, slavery?

The more important point here is that time frames can refer, not just to factual situations that differ by degree (more remote causes) but may also include ultimately different types of facts, what has been referred to here as 'conditions' or 'deeper causes.' Thus it is the difference between a woman who is convicted of murder and the same woman who is a victim of battered woman syndrome. Kelman makes this point abundantly clear when discussing the conduct of theft situated in narrow time frames:

'The incidental focus that supports this limitation of issues- a focus that blurs the "crime" by freezing or taking for granted the background conditions in which the "crime" is committed- serves important ideological purposes...it normalizes, sanitizes, and decriminalizes the property holdings of dominating groups which are unlikely to be traceable to single, easily identifiable disruptive incidents. The dominant rarely appear "criminal" when the implicit theory of criminality is disruption, when the only form of crime we comfortably discuss is temporally limited'. ${ }^{125}$

\footnotetext{
${ }^{124}$ Alan Norrie, Crime, Reason and History: A Critical Introduction to Criminal Law (Cambridge University Press, 2011) 137-140

${ }^{125}$ Mark Kelman, 'Interpretive Construction in the Substantive Criminal Law' (1981) 33, 4 Stanford Law Review, 666
} 
Narrow time frames, broad time frames (including 'conditions' or 'deeper causes') provide new content for legal norms and undermine ostensibly rule like forms to produce standards. Therefore, the formal realizability of the legal norm is contingent on the time frames adopted.

\section{Time Frame Indeterminacy and Precedent}

As well as underwriting the paired rhetorical arguments of free will-determinism and rules-standards in CLS's claim of indeterminacy, I will also argue that time frame indeterminacy underwrites Llewellyn's janus-faced theory of precedent.

Llewellyn suggests that a case can be read in two divergent and therefore indeterminate ways. To restate his thesis once again; a potentially binding common law rule can be read either as a) 'if $A$, then $Z$ ' or b) 'if $A$ and $F$, then $Z{ }^{\prime}{ }^{126}$ The first reading a) of the previous rule requires just one of the facts to obtain in order to engage the binding force of the precedent whereas the second reading b) requires multiple facts to obtain. $A$ and $F$ can refer either to the ratio of the case and it's level of abstraction ('pale magenta Buick cars' or 'vehicles') and/or the reading of obiter statements (or even just language). Consequently, the reading of either/or ratio/obiter/language and their level of generality may be used to either bind or distinguish the case at hand. Taking Llewellyn's example- a hypothetical case at hand, which involves a black Ford, could be distinguished on a strict reading of precedent; or could be binding, if the common law rule was abstracted to 'vehicles'. Importantly however (perhaps something underestimated by Llewellyn) this involves not just how the previous case is read but also what is factually relevant in the case at hand.

Two things are important here. Firstly, sameness or difference between the precedent and the case at hand is contingent on the level of abstraction in which a) the former case is read and interpreted b) identifying the components of the binding rule (ratio/obiter/language) and c) importantly, what is factually relevant in the case at

${ }^{126}$ Ken Kress, 'Legal Indeterminacy’ (1989) 77, 2 California Law Review, 299 
hand (ie what time frames are adopted). Secondly, 'a theory of which facts are relevant would be a theory of common law adjudication'. ${ }^{127}$ In other words, it is the facts which determine whether a legal rule is engaged and therefore binding on the case at hand (as is apparent in the comparison between Ahluwalia and Baillie). Once again, this appears to signal the chronological priority of factual construction and, by extension, time frames.

Admittedly, as 'subconscious constructs', the use of narrow or broad time frames (particularly our enriched version of broad time frames) are hardly going to be explicitly mentioned in judgments. However, it will be facts that are indicative of the types of time frames adopted. To go back to Norrie's reading of the Scarman report, we know that if a judge mentions 'poor social environment, racial discrimination, police harassment' for example, she is employing a broad time frame.

Time frame indeterminacy therefore, underwrites ALR critiques of legal formalism in that they similarly make a claim to the sameness or difference between cases, which is at the heart of Llewellyn's reading of precedent. The case at hand can be distinguished or bound based, not so much on the level of generality of the precedent, but on the time frames adopted in the case at hand. In $R v$. Ahluwalia ${ }^{128}$ and $R v$. Baillie (John Dickie $)^{129}$, the latter appears to have been distinguished from the former as the former had adopted too narrow a time frame to constitute 'a sudden and temporary loss of self-control' for the purposes of provocation ('some phenomenon' and the 'trigger'). Ahluwalia was read as adopting a narrow time frame in determining 'a sudden a temporary loss of self-control' (which did not obtain in that case) but Baillie can be read as distinguishing itself on the basis of adopting a broad time frame in constituting this limb of the provocation test. Indeed, we could also envisage a situation in which a case at hand is distinguished from a near identical precedent (both the precedent and the case at hand involve pale magenta Buick cars) on the basis of adopting a time frame different to that adopted in the precedent. For example, there could be 'conditions' or 'deeper causes' which warrant distinction and therefore overruling (I am thinking more 'poor social environment or racism' rather than the absurd differences which Llewellyn also derides such as hair colour). In Ahluwalia, the departure from an analogous case was effectively the adoption of a broader time frame ${ }^{130}$ which introduced into the construction of facts, her history of being a victim of violence. These time

\footnotetext{
${ }^{127}$ Ken Kress, 'Legal Indeterminacy’ (1989) 77, 2 California Law Review, 300-301

${ }^{128} R$ v. Ahluwalia [1993] 96 Cr. App. R. 31

${ }^{129} R$ v. Baillie (John Dickie) [1995] 2 Cr. App. R

'The battered spouse's defence lengthens the time horizon of the subject and makes the subject exist through time. The lawyers and scholars who created this defence argued that the time-horizon for self-defence in this case was five years not five-minutes.
} 
frames constituted the then newly established battered woman syndrome for the purposes of diminished responsibility. Time frame indeterminacy therefore, in part, determines what is the same and what is different between a case at hand and a precedent. Sameness and difference would be contingent on whether a narrow/broad time frame is adopted in both the precedent and the case at hand.

\section{The degree of Time Frame Indeterminacy}

If the account of the chronological priority of time frame indeterminacy is convincing, in other words that factual relevancy is decided prior to the application of the rule (disposing therefore with subsumptive or correspondence theories of law and fact), then the next question ought to be the degree of this indeterminacy. This warrants a much more detailed discussion than the one I can offer here. However, some general remarks can be made as to whether time frame indeterminacy is moderate (and therefore manageable) or strong (and potentially nihilistic). There are certain 'stabilising factors' in the interpretation of legal texts generally. Fiss for example describes the 'disciplining rules' ${ }^{131}$ of a specific interpretive community that direct judge's to appropriate meanings in certain contexts. Indeed, there is often a context, ${ }^{132}$ tradition, ${ }^{133}$ or 'form of life' ${ }^{134}$ in that 'we are always already constrained by the suppositions and conventions that guided us... we cannot simply chose our way in and out of that interpretive community'. ${ }^{135}$ Specifically in response to the claims of indeterminacy, Kress offers one of the more powerful rebuttals of radical indeterminacy, particularly within the context of legitimating the law as a distinct normative order, by undermining such critiques as parodying or caricaturing what the law and legal reasoning actually is. ${ }^{136}$ It is also worth pointing out the level of abstraction at which claims of indeterminacy are often levelled at. The abstracted legal norm of vehicles may be inherently determinate regardless of whether an essentialist or purposive approach to meaning is taken, but case law has often established what facts do constitute

Now what is that but a broadening, a temporal stretching, if you will, of the legal subject? Yet at the same time that they are using the traditional genre of legal arguments about the subject and self-defence, these advocates are also calling that genre into questionthe apparently fixed world of free will and its limited exceptions around which criminal law is constructed'. James Boyle, 'Is Subjectivity possible? The Postmodern Subject in Legal Theory' (1991) 62 University of Colorado Law Review, 522 ${ }^{131}$ Owen Fiss, 'Objectivity and Interpretation' (1982) 34 Stanford Law Review

132 Joseph Singer, 'The Player and the Cards: Nihilism and Legal Theory' 94, 1 (1984) 20-21

${ }^{133}$ Joseph Singer, 'The Player and the Cards: Nihilism and Legal Theory' 94, 1 (1984) 53

${ }^{134}$ Conor Casey, 'Legal Indeterminacy: Causes and Significance' (2015) 18 Trinity College Law Review, 47

${ }^{135}$ Conor Casey, 'Legal Indeterminacy: Causes and Significance' (2015) 18 Trinity College Law Review, 48

${ }^{136}$ Ken Kress, 'Legal Indeterminacy' (1989) 77, 2 California Law Review 
a vehicle, for example, for the purposes of law. Meaning generally therefore becomes more determinate as time passes and can begin to ossify, though it can never be fully determinate.

As for stabilizing time frames which are adopted, that is another question. Stabilizing influences could be linked to political views or paradigms. Kelman, for example, suggests that there is a tendency toward adopting narrow time frames which reinforces the paradigmatic free will, and therefore responsible, subject of law. Lindsay Farmer quotes Scott Veitch saying that 'legal conceptions of responsibility are organized according to conceptions of proximity and foresight, which refer to particular roles and duties, and according to a narrow conception of foreseeable consequences'. ${ }^{137}$ Perhaps the stabilizing influences are what we understand today as Modernity and the responsible, reasonable, deracinated subject.

\section{Conclusion}

Time frame indeterminacy posits that factual construction is, in part, contingent on the narrow or broad time frames adopted. However, without instruction on which time frames to adopt and when, what is deemed factually relevant is indeterminate. Implicit in this position, is the rejection of a correspondence or subsumptive theory of adjudication, that legal norms simply mirror facts. This paper has tried to push this claim of indeterminacy further by suggesting that it underwrites, or is chronologically prior to the application of legal norms. Time frame indeterminacy is the foundation upon which the contradictions beset in legal formalism are identified by CLS and ALR. Time frame indeterminacy explains the simultaneous presence, and therefore contradictions of free will and determinist discourses in legal liberalism, as well as the operation of both rule-forms and situation-sensitive standard-forms of legal norms. Additionally, it also underlines the indeterminacy derived from differential readings of precedent on the basis that the core of Llewelyn's theory, that sameness or difference between cases is contingent on how the precedent is read, requires the primacy of what is factually relevant in both cases- in other words, what time frames are adopted.

\footnotetext{
${ }^{137}$ Lindsay Farmer, 'Time and Space in Criminal Law' (2010) 13, 2 New Criminal Law Review: An International and Interdisciplinary Journal, 340
} 
In these attempts to further the claim of the chronological priority of time frame indeterminacy, one could accuse me of making certain 'sequential presumptions' about the process or craft of adjudication. This position, expanding upon Kelman, stipulates a clear causal sequence from fact construction, then norm application (or formal realizability), followed by rational rhetoricism. It may be that these stages occur in different orders, or that there is a dialectical relation between the different elements.

The final point is to link this back to a growing interest examining the intersection of temporality and law, and to re-shine $e^{138}$ some of the key claims of the critical legal literature. The general marginalisation of time has been explained as the 'consequence of modernity' in that it is 'seen as objective and external to human experience, and as such have come to be taken for granted' ${ }^{139}$ This paper lays some of the groundwork for revising (or awakening the general silence of) temporality in questions of law, specifically, the determinacy of law. Whether time frame indeterminacy is really a 'subconscious construct' or part of a tradition tied to a particular moment, as a claim that precedes legal interpretation, it warrants further discussion. Alongside correspondence and subsumptive theories of adjudication therefore, this paper offers another theory or synoptic judgment. Importantly, with the ascendancy of temporality in parts of legal scholarship, this paper begins to ride that wave by dismissing the epiphenomenality of time, instead asserting its centrality in adjudication.

\section{Bibliography}

Bingham, Tom (2010) The Rule of Law (Penguin Books)

\footnotetext{
${ }^{138}$ M D A Freeman, 'Introduction to Jurisprudence' ( $8^{\text {th }}$ ed. 2008 Sweet \& Maxwell) pp 1224

${ }^{139}$ Farmer (n 73) 341
} 
Boyle, James. (1991) ‘Is Subjectivity possible? The Postmodern Subject in Legal Theory’ 62 University of Colorado Law Review

Bjarup, Jes \& Blegvad, Mogens (eds) (1994) Time, Law and Society: Edited Proceedings of a Nordic Symposium at Sandbjerg Gods (Franz Steiner Verlag)

Bellamy, Richard (ed.) (2005), The Rule of Law and Separation of Powers (Ashgate)

Cardozo, Benjamin. (1921) The Nature of the Judicial Process (Yale University Press)

Casey, Conor. (2015) 'Legal Indeterminacy: Causes and Significance’ 18 Trinity College Law Review

Dicey, Albert. (1945) An Introduction to the Study of the Law of the Constitution (Macmillan)

Engel, David. (1987) 'Law, Time and Community’ 21, 4 Law and Society Review

Farmer, Lindsay. (2010) 'Time and Space in Criminal Law' 13, 2 New Criminal Law Review: An International and Interdisciplinary Journal

Fiss, Owen. (1982) ‘Objectivity and Interpretation’ 34 Stanford Law Review

Flood, Emmet T. (1991) ‘Fact Construction and Judgement in Constitutional Adjudication’ 100, 6 The Yale Law Journal

Freeman, M D A. (2008) Introduction to Jurisprudence (Sweet \& Maxwell)

Gordon, Robert. (1988) 'Law and Ideology’ 3,1 Tikkun

Grabham, Emily. (2016- Forthcoming) Doing Things with Time (University of Toronto Press, 2016)

Greenhouse, Carol. (1996) A Moment's Notice: Time Politics Across Cultures (Cornell University Press)

Hogue, Arthur. (1966) Origins of the Common Law (Indiana, University Press)

Hutchinson, Allan and Monahan, Patrick (eds.) (1987) The Rule of Law: Ideal or Ideology (Carswell)

Kairys. David (1988) (ed.) The Politics of Law (Basic Books)

Kelman, Mark. (1987) A Guide to Critical Legal Studies (Harvard University Press) 
Kelman, Mark. (1981) 'Interpretive Construction in the Substantive Criminal Law' 33, 4 Stanford Law Review

Kennedy, Duncan. (1976) ‘Form and Substance in Private Law Adjudication’ 89 Harvard Law Review

Kennedy, Duncan. (1973) 'Legal Formalism’2, 2 The Journal of Legal Studies

Kress, Ken. (1989) ‘Legal Indeterminacy’ 77, 2 California Law Review

Kripke, Saul (1982) Wittgenstein on Rules and Private Language: An Elementary Exposition (Harvard University Press)

Lefebvre, Alexandre. (2008) The Image of Law: Deleuze, Bergson, Spinoza (Stanford University Press)

Leiter, Brian. (1995) 'Legal Indeterminacy’ 1 Legal Theory

Leiter, Brian and Coleman, Jules. (1993) 'Determinacy, Objectivity and Authority' 142, 2 University of Pennsylvania Law Review

Llewellyn, Karl. (1930) The Bramble Bush (Oceana Publications)

Llewellyn, Karl. (1960) The Common Law Tradition (Brown \& Company)

Lucy, William. (1999) Understanding and Explaining Adjudication (Oxford University Press)

Naffine, Ngaire (2009) Law's Meaning of Life: Philosophy, Religion, Darwin and the Legal Person (Hart Publishing)

Naffine, Ngaire. (2003) 'Who are Law’s Persons? From Cheshire Cats to Responsible Subjects’ Modern Law Review

Norrie, Alan. (2011) Crime, Reason and History: A Critical Introduction to Criminal Law (Cambridge University Press)

Schauer, Frederick. (1988) 'Formalism' 97, 4 The Yale Law Journal Schlag, Pierre J. (1985) Rules and Standards, 33 UCLA Law Review

Singer, Joseph. (1984) 'The Player and the Cards: Nihilism and Legal Theory’ 94, 1 The Yale Law Journal Tamanaha, Brian. (2004) On the Rule of Law (Cambridge University Press) 
Tushnet, Mark. (1983) 'Following the Rules Laid down: A Critique of Interpretivism and Neutral Principles' 96, 4 Harvard Law Review

Twinning, William and Myers, David. (2012) 'How to Do Things with Rules' (Cambridge University Press)

Unger, Roberto. (1974) Knowledge and Politics (Free Press)

Valverde, Mariana. (2015) Chronotopes of Law: Jurisdiction, Scale and Governance (Routledge)

von Benda-Beckmann, Keebet. (2014) 'Trust and the Temporalities of Law’ 46, 1 The Journal of Legal

Pluralism and Unofficial Law

Wendell Holmes, Oliver. (1881) The Common Law (The Lawbook Exchange)

White, Morton (1947) 'Social Thought in America: The Revolt Against Formalism' 8, 2 Journal of the History of Ideas

Winter, Steven (1990) 'Indeterminacy and Incommensurability in Constitutional Law' 78 California Law Review

\section{$\underline{\text { Cases }}$}

Brown v. Board 347 U.S. 483

Duport Steel v. Sirs [1982] 1 WLR 142

Plessy v. Ferguson 163 U.S. 537

State v Preslar (1885) 48 NC 41718

R v. Ahluwalia [1993] 96 Cr. App. R. 31

R v. Baillie (John Dickie) [1995] 2 Cr. App. R

$R v$ Duffy [1949] 1 AER 932

$R$ v. $R$ [1991] 3 WLR 767 


\section{$\underline{\text { Reports }}$}

Lord Scarman, The Brixton Disorders 10-12 April 1981 Report Command 8932 